\title{
Violence against women: historical trajectory of a care program (Curitiba - 1997-2014)
}

Violência contra mulheres: trajetória histórica de um programa de atenção (Curitiba - 1997-2014)

Violencia contra las mujeres: la trayectoria histórica de un programa de atención (Curitiba - 1997-2014)

Terezinha Maria Mafioletti', Aida Maris Peres', Liliana Muller Larocca', Mariana Purcote Fontoura'

' Universidade Federal do Paraná. Curitiba, Paraná, Brazil.

How to cite this article:

Mafioletti TM, Peres AM, Larocca LM, Fontoura MP. Violence against women: historical trajectory of a care program (Curitiba - 1997-2014). Rev Bras Enferm [Internet]. 2018;71(6):2907-15. DOI: http://dx.doi.org/10.1590/0034-7167-2017-0583

Approval: 03-12-2018

\begin{abstract}
Objective: To analyze the historical trajectory and the contributions of the Programa de Atenção às Mulheres em Situação de Violência (Program of Care to Women Victims of Violence) of Curitiba. Method: Research with documentary and local approach, inspired by the Dimension of Political History, to unveil power relations, political representations, symbols and discourses. Eighty-eight sources were used for the period 1997-2014. The data collection was performed in May 2016 and presented in the timeline modality. Results: The historical trajectory of the program indicates intersectoral and interinstitutional experience that has been increasing and originating important innovations in care to women based on humanization and from the perspective of comprehensiveness. Final considerations: Historicizing the Program contributed to the reflection on the construction of practices aimed at confronting violence, the need for intersectoral actions and looks that involve its complexity. Descriptors: Violence Against Women; Intersectorial Collaboration; Continuous Health Care Network; Intersectorial Collaboration; Evaluation.
\end{abstract}

\section{RESUMO}

Objetivo: Analisar a trajetória histórica e as contribuições do Programa de Atenção às Mulheres em Situação de Violência de Curitiba. Método: Pesquisa com abordagem documental e local, inspirada na Dimensão da História Política, para descortinar relações de poder, representações políticas, símbolos e discursos. Foram utilizadas 88 fontes referentes ao período de 1997-2014. A coleta de dados foi realizada em maio de 2016 e apresentada na modalidade linha do tempo. Resultados: A trajetória histórica do programa indica experiência intersetorial e interinstitucional que foi se ampliando e originando importantes inovações na atenção às mulheres pautadas na humanização e na perspectiva da integralidade. Considerações finais: Historicizar o Programa contribuiu na reflexão acerca da construção de práticas voltadas ao enfrentamento da violência, a necessidade de ações intersetoriais e olhares que envolvam sua complexidade.

Descritores: Violência Contra a Mulher; Intersetorialidade; Rede de Cuidados Continuados de Saúde; Ação Intersetorial; Avaliação.

\section{RESUMEN}

Objetivo: Analizar la trayectoria histórica y las contribuciones del Programa de Atención a las Mujeres en Situación de Violencia de Curitiba. Método: Investigación con enfoque documental y local, inspirada en la Dimensión de la Historia Política, para revelar relaciones de poder, representaciones políticas, símbolos y discursos. Se utilizaron 88 fuentes para el período $1997-$ 2014. La recolección de datos fue realizada en mayo de 2016 y presentada en la modalidad línea del tiempo. Resultados: La trayectoria histórica del programa indica una experiencia intersectorial e interinstitucional, que se ha ido ampliando y originando importantes innovaciones en la atención a mujeres pautadas en la humanización y en la perspectiva de la integralidad. Consideraciones finales: Historizar el programa contribuyó a la reflexión acerca de la construcción de prácticas dirigidas al enfrentamiento de la violencia, la necesidad de acciones intersectoriales y miradas que involucren su complejidad.

Descriptores: Violencia Contra la Mujer; Interseccionalidad; Red de Cuidados Continuos de la Salud; Acción Intersectorial; Evaluación. 


\section{INTRODUCTION}

Violence against women is a complex phenomenon that permeates unequal gender relations. Recognized as a serious health problem and violation of rights, it requires actions and public policies in the areas of prevention, coping and recovery of health articulated intersectorally to ensure comprehensive care to women ${ }^{(1-2)}$.

It is estimated that approximately $35 \%$ of women suffer physical and/or sexual violence worldwide, most of which are caused by their partners ${ }^{(1)}$. A comparative study with black women from the Caribbean and the United States showed that rates of mental and physical health problems were higher among women who experienced intimate partner violence compared to women who did not experience violence ${ }^{(2)}$. In Brazil, between 2011 and 2015, 893,751 cases of interpersonal and self-inflicted violence were reported, of which approximately $70 \%$ were violence against women ${ }^{(3)}$.

The high homicide rates against women in the country are also high in 2013, with 4.8 (homicides for 100,000 women) in 2013, with the Paraná State at 5.2, and the municipality of Curitiba at 6.2 (homicides for 100,000 women), ranked $19^{\text {th }}$ and $18^{\text {th }}$ respectively in the national ranking of women's murders ${ }^{(4)}$.

In Curitiba, based on the Programa de Enfrentamento da Violência (Program to Combat Violence against Women), launched in 2002, data show that there has been a percentage increase of more than $1800 \%$ of notifications over the period from 2002 to 2015 . With regard to addressing the phenomenon, one can highlight the advances obtained after years of struggles of the feminist and women's movements, which have resulted in the development of laws, programs and projects in several areas, such as the promulgation of the Maria da Penha Law (The Maria da Penha law (Portuguese: Lei Maria da Penha) is the informal title for Brazil' s Federal Law 11.340, enacted by the National Congress of Brazil and sanctioned by former-President Luiz Inácio Lula da Silva on 7 August 2006. The law regulates violence against women in every aspect of the domestic life and is regarded as a milestone in terms of national legislation on gender), the Pacto Nacional de Enfrentamento da Violência contra as Mulheres (National Pact for Ending Violence against Women), implementation and implementation of public policies to combat, prevent and promote the culture of peace. Among the most important is the expansion of the Network to Combat Violence Against Women, with the installation of Reference Centers, Houses Shelter, Specialized Police Stations, House of Brazilian Women and in the area of Health, the creation of the Surveillance System for Violence and Accidents (VIVA Vigilância de Violências e Acidentes), among others.

In this sense, the creation of a Reference Programa de Atenção às Mulheres em Situação de Violência (Program of Care to Women Victims of Violence) domestic and sexual in the Municipality of Curitiba, with intersectoral collaboration in operation for more than 16 years, can be understood as an important step towards confronting violence against women. Therefore, this study aimed to: Analyze, through a timeline, the historical trajectory and the contributions of a Programa de Atenção às Mulheres em Situação de Violência (Program of Care to Women Victims of Violence) in the south of the country.

\section{OBJECTIVE}

To analyze the historical trajectory and the contributions of the Programa de Atenção às Mulheres em Situação de Violência (Program of Care to Women Victims of Violence) of Curitiba city.

\section{METHOD}

\section{Ethical aspects}

The research project was submitted and approved by the Research Ethics Committee of a Brazilian higher education institution, following the ethical norms in force in the country.

\section{Theoretical-Methodological framework}

In the discussion of violence against women, is necessary to make explicit that there are no facts that are exclusively economic, political or cultural, but rather, interactions of a given social reality ${ }^{(5)}$. Thus, we analyzed 88 documents produced between 1997 and 2014, which allowed us to dialogue with the sources and to recognize the line of care established for the implementation of the Programa de Atenção às Mulheres em Situação de Violência (Program of Care to Women Victims of Violence) of Curitiba. The research was inspired by the dimension of Political History, as a field of power relations, political representations, symbols and discourses ${ }^{(5)}$.

\section{Type of study}

It is characterized as qualitative research. The approach, or field and observation was documentary and local, whose domain (historical agent) lies in Women's History ${ }^{(5)}$.

\section{Methodological procedures}

\section{Study setting}

The study setting was in Curitiba, capital of Paraná State, in the southern region of Brazil, with an estimated population of $1,892,242$ inhabitants. In 2014, Curitiba's crude birth rate was 13.31 for 1,000 inhabitants; infant mortality rate was 7.70 for maternal mortality, 36.27 for fertility and $1.62 \%$ for fertility. The total population of the Metropolitan Region of Curitiba is $3,493,742$ inhabitants, representing $45 \%$ of the population of the state and $60 \%$ of the urban population of Paraná State ${ }^{(6)}$.

\section{Data source}

The documents used as research sources were program protocols, release documents, award documents, articles, dissertations and theses related to the program, annual reports, surveys and resolutions that were significant in the creation of the Programa de Atenção às Mulheres em Situação de Violência (Program of Care for Women Victims of Violence), as well as those that preceded its creation, totaling 88 documents, covering the period from 1997 to 2014

\section{Collection and organization of data}

The documents were obtained from the coordination of Diseases and Noncommunicable Diseases (NCD) of the MHO and collected in the period of May 2016. They were classified and organized by type, date and content for later analysis. 


\section{Data analysis}

The analysis of the data included the classification and organization of the information collected, carried out through careful reading of the material and identification of the main points, observing the pertinence and relevance for the object of study. It was decided to elaborate a time line, even recognizing the non-linearity of the facts, but as an organizational strategy, which we consider capable of understanding and establishing relationships between the dimension, approach and domain used to read the sources.

\section{RESULTS}

This article presents the historical trajectory of Curitiba's Programa de Atenção às Mulheres em Situação de Violência (Program of Care to Women Victims of Violence), initially based on the documents presented before its creation, presented in detail in Chart 1, in a total of 8 documents referring to research on violence carried out in the city of Curitiba and resolutions that had strategic importance in the creation of the program.

Subsequently, the sources from their creation are analyzed, detailed in Chart 02, which cover 80 documents between service protocols, articles, theses and dissertations about the program, awards received, annual epidemiological reports, among others.

\section{Setting before the creation of the program}

To analyze this Reference Program, it is necessary to reflect on the panorama of important actions and policies that preceded it. Between 1997 and 2001, three surveys were conducted in the city of Curitiba, indicated in Chart 1, lines 1, 2 and 5, which had a great impact on the unveiling of the violence setting, especially violence against women, allowing an approximation of the problem. They revealed the absence of an integrated information system and the need to organize policies to combat violence against women.
In addition to these investigations, some resolutions were significant in the process that culminated in the creation and launch of the program. Resolution 10/99 of the State Health Council (line 3) that regulated the pregnancy termination service due to rape in Paraná State, Resolution 14/2001 (line 4), which established the policy to provide assistance to women who suffer violence in Paraná State, providing that assistance services are structured in the form of Integrated Networks and Resolution 15/2001 (line 4), which created the Interagency Management Committee to encourage, monitoring of the development of Integrated Networks, preparation of studies and proposals for intervention on the causes of violence.

It was also highlighted Joint Resolution 02/2002 (line 6) between the State Office of Health (SESA - Secretaria de Estado da Saúde) and the State Office of Public Security (SESP - Secretaria de Estado da Segurança Pública), whose purpose was the integration and humanization of care related to sexual violence, which allowed the assignment of SESA physicians to the Legal Medical Institute (IML - Instituto Médico Legal), for the purpose of conducting the ad hoc report of sexual violence in the reference hospitals within 72 hours of the occurrence of violence, without the need for women to go through the Woman and IML. It was incumbent upon the Municipal Health Office of Curitiba to establish a partnership with the reference hospitals for the treatment of sexual violence, the State Office of Health for the transfer of doctors and supplies, and the State Office of Public Security for the training and follow- hoc.

The historical course of unveiling violence against women in Curitiba, through investigations and approved resolutions, gave visibility to the urgency of ensuring care for women who suffer violence, as well as demonstrating the need to organize strategies to address the problem. This reality allied to the social demands of the feminist and women's movements formed a basic setting for the creation of the Program.

Chart 1 - Documents prior to the creation of the Programa de Atenção às Mulheres em Situação de Violência (Program of Care to Women Victims of Violence) of Curitiba (1997 - 2002)

\begin{tabular}{|c|c|l|l|}
\hline Line & Year & \multicolumn{1}{|c|}{ Documents } & \multicolumn{1}{|c|}{ Amount } \\
\hline 1 & 1997 & Urban Violence Survey: Map of risk of violence in Curitiba & 1 \\
\hline 2 & 1999 & $\begin{array}{l}\text { Research Characterization of the victims who sought the IML-Survey carried out in the IML - Clinical } \\
\text { Medical Legal 1998-1999. }\end{array}$ & 1 \\
\hline 3 & 1999 & $\begin{array}{l}\text { Resolution 10/99 of the State Health Council - CES-PR } \\
1\end{array}$ & 3 \\
\hline 5 & 2000 & $\begin{array}{l}\text { Strategic Plan for Network Implementation (2002): Approved in Resolutions 14 and 15/2001/CES. } \\
\text { Violence Against Women Survey: victims and aggressors - survey conducted at the Women's Police } \\
\text { Station, held in October 2009 to May 2000. Curitiba, 2001. }\end{array}$ & 1 \\
\hline 6 & 2002 & $\begin{array}{l}\text { Joint Resolution n. 02 of the State Office of Public Security (SESP - Secretaria de Estado da Segurança } \\
\text { Pública) and the State Office of Health (SESA - Secretaria de Estado da Saúde). }\end{array}$ & 1 \\
\hline
\end{tabular}


Setting of the creation and development of the Program

On March 8, 2002, the Municipal Health Office launched the Program, with the purpose of guaranteeing care to women in situations of sexual and domestic violence through the organization of services and flows of Women's Health Care and the articulation with other partners ${ }^{(7)}$. This program was created with a concept of intersectoral work, and, at the same time, an Rede Intersetorial de Atenção às Mulheres em Situação de Violência (Intersectoral Network of Care to Women Victims of Violence) was created, with the purpose of articulating the various organs, institutions and social movements that give support to the Program. to organize services and careflows to violence against women.

Chart 2 - Documents after the creation of the Programa de Atenção às Mulheres em Situação de Violência (Program of Care to Women Victims of Violence) of Curitiba (2002 - 2014)

\begin{tabular}{|c|c|c|c|}
\hline Line & Year & Documents & Amount \\
\hline 1 & 2002 & Program launch document & 1 \\
\hline 2 & 2002 & Protocol of the Program (2002) & 1 \\
\hline 3 & 2002 & $\begin{array}{l}\text { Article: Shimazaki, M. E.; Lopes, M. G. D.; Oliveira, V. L. A. Saúde sim, violência não: Programa Mulher } \\
\text { de Verdade. Jornal Fêmea, CFEMEA, n. 117. October. } 2002 .\end{array}$ & 1 \\
\hline 4 & 2003 & $\begin{array}{l}\text { Article: Shimazaki, M. E.; Lopes, M. G. D.; Oliveira, V. L. A. Saúde sim, violência não: Programa Mulher } \\
\text { de Verdade. Health Disclosure for Discussion, Rio de Janeiro State, n. 26, p. 51-57, April } 2003 .\end{array}$ & 1 \\
\hline 5 & 2004 & Protocol of the Program & 1 \\
\hline 6 & 2008 & Protocol of the Program & 1 \\
\hline 7 & 2008 & $\begin{array}{l}\text { Article: Oliveira, V. L. A. Ações de vigilância, prevenção e atenção à violência em Curitiba. In: Violên- } \\
\text { cia: uma epidemia silenciosa, Seminários Regionais/Conselho Nacional de Secretários de Saúde. - } \\
\text { Brasília: CONASS, } 2008 .\end{array}$ & 1 \\
\hline 8 & 2008 & $\begin{array}{l}\text { Article: Santos, T. A. A. Centro de referência e atendimento psicossocial e jurídico à mulher em situação } \\
\text { de violência de Curitiba e região metropolitana. In: Violência: uma epidemia silenciosa, Seminários } \\
\text { Regionais. Conselho Nacional de Secretários de Saúde. - Brasília: CONASS, } 2008 .\end{array}$ & 1 \\
\hline 9 & 2008 & $\begin{array}{l}\text { Essay: Corrêa, M. E. C.; Labronici, L.M. A enfermeira desvelando o significado do atendimento às vítimas } \\
\text { de violência sexual expresso pelos profissionais de Saúde. Dissertação de Mestrado. Universidade Federal } \\
\text { do Paraná, Sector of Health Sciences, } 2008\end{array}$ & 1 \\
\hline 10 & $\begin{array}{l}2008 \text { to } \\
2012\end{array}$ & Training documents on the program for health professionals, partners and the community. & 50 \\
\hline 11 & 2009 & $\begin{array}{l}\text { Ministry of Health award. } 9^{\text {th }} \text { edition of the Mostra Nacional de Experiências Bem-Sucedidas em Epide- } \\
\text { miologia, Prevenção e Controle de Doenças, (Expoepi) in the category "Inovações na gestão da vigilância } \\
\text { de agravos e doenças não transmissíveis e da promoção da saúde" com o trabalho "Humanização no } \\
\text { atendimento às vítimas de violência sexual: o Instituto Médico Legal vai ao Hospital" }\end{array}$ & 1 \\
\hline 12 & 2010 & $\begin{array}{l}\text { Award for Public Policies for Women (Premiação Secretaria de Políticas Públicas para Mulheres), category } \\
\text { "Good Practices in the Application, Dissemination and Implementation of the Maria da Penha Law" }\end{array}$ & 1 \\
\hline 13 & 2010 & $\begin{array}{l}\text { Thesis: Okabe I. Violência contra a mulher: uma proposta de indicadores de gênero na família [tese]. } \\
\text { São Paulo State: Escola de Enfermagem, Universidade de São Paulo; } 2010\end{array}$ & 1 \\
\hline 14 & 2011 & $\begin{array}{l}\text { Article published: DUARTE, A. H. C.; CONING, S. G. S. Vítimas de Violência Sexual e Desafios na } \\
\text { Prática Multiprofissional: Breves Apontamentos. Anais do II Simpósio Gênero e Políticas Públicas. Uni- } \\
\text { versidade Estadual de Londrina. August, } 2011\end{array}$ & 1 \\
\hline 15 & 2012 & $\begin{array}{l}\text { Americas Award. United Nations Institute for Training and Research (UNITAR - Instituto das Nações Unidas para } \\
\text { Treinamento e Pesquisa). International Training Center for Local Actors for Latin America (CIFAL - Centro Inter- } \\
\text { nacional de Formação de Atores Locais para América Latina), in the category of infant mortality reduction I } \\
\text { Honorable mention of the } 12^{\text {th }} \text { Expoepi in } 2012 \text {. For the development of the experience "Comprehensive care } \\
\text { for women in situations of violence adaptation of the National Notification Card to local reality" }\end{array}$ & 2 \\
\hline
\end{tabular}


Chart 2 (concluded)

\begin{tabular}{|c|c|l|c|}
\hline Line & Year & \multicolumn{1}{c|}{ Documents } & Amount \\
\hline 16 & $\begin{array}{c}2002 \text { to } \\
2014\end{array}$ & $\begin{array}{l}\text { Reports with epidemiological analyzes of the Program. Annual publications with analysis of the cases } \\
\text { notified by the Program }\end{array}$ & 14 \\
\hline 17 & 2014 & $\begin{array}{l}\text { Joint Resolution n. 03 of the State Office of Public Security (SESP - Secretaria de Estado da Segurança } \\
\text { Pública), the State Office of Health (SESA - Secretaria de Estado da Saúde) and the Municipal Health Of- } \\
\text { fice (SMS - Secretaria Municipal de Saúde) }\end{array}$ & 1 \\
\hline & $\begin{array}{l}\text { Total } \\
80\end{array}$ \\
\hline
\end{tabular}

The Program established, according to Resolution 02/2002 that assistance for cases of sexual violence would occur within 72 hours after the occurrence. To this end, three reference hospitals were included, one for children up to 12 years of age. In these cases, the patients receive medical attention from the expert in the reference hospitals, thus avoiding the 'pilgrimage' or 'critical route', so common in this kind of attention ${ }^{(8)}$. This service was very important and innovative in the country, because one of the problems faced by the organization of the service network for women who suffer violence refers to the necessary agility in the care provided, which assures the adequate and quick response between the various involved institutions (medical and legal), which also ensure the termination of gestation due to rape. Reference services for sexual violence also serve the MRC and other municipalities in the state and some cases in other states. The Rede Intersetorial de Atenção às Mulheres em Situação de Violência (Intersectoral Network of Care to Women Victims of Violence), in turn, has the purpose of articulating the various organs, institutions and social movements that support the Program, in order to organize the services and flows of Women's Health Care, to discuss cases requiring intersectoral intervention and articulation with other partners, taking into account the various needs related to health, social protection, public security (police station and court, IML) and justice - civil judicial measures necessary ${ }^{(8)}$.

The first Protocol of the Program was published in 2002 with the objective of standardizing the flows of care, referral and guidance regarding violence against women ${ }^{(7)}$. Included in this document are the partners that made up the program and assisted in the design and implementation of the program, including Public Safety, Justice, Health, State and Municipal Women's Councils, Scientific Societies, Universities and NonGovernmental Organizations.

This document has conceived that one of the main purposes of the Program is based on the solidarity of women who suffer violence, seeking to minimize pain, avoid harm and reduce harm. In this way, health professionals must be able to detect risks, identify undeclared violence, and assist and accompany women in situations of violence until they can reorganize their lives ${ }^{(7)}$.

The protocol brought theoretical contributions on gender violence and violence data in Curitiba, presented ways of approaching the cases and the relevance of the notification of the attendance. In addition, it presents an organization of services for attention to women in situations of violence, focusing on the humanization of care, including its debureaucratization, integrated and simultaneous actions, avoiding the pilgrimage in several services as well as the repetition of the report on what happened and streamlining the prophylaxis of STDs, AIDS and pregnancy ${ }^{(7)}$.

In addition, the competencies and procedures of health units and referral hospitals for the treatment of sexual violence were established. The functions of the health units are related to the gateway to the Program, the reception of the users, service, emergency contraception, referral to specialized services and continuity of care, including performing prenatal care in cases of pregnancy due to rape and in cases of adoption, referring to the $2^{\text {nd }}$ Childhood and Youth Court. The competence of referral hospitals to serve sexual violence refers to laboratory tests, emergency contraception and STD/AIDS prophylaxis, psychological counseling, interruption of pregnancy due to rape, if the contrary to forwarding for prenatal care in the health units ${ }^{(7)}$

Most of the competencies and procedures in the service are related to sexual violence, and in addition, there is an explanatory session in the protocol on legal measures referring exclusively to sexual violence and the presentation of the 'Form of Assistance to Women Victims of Sexual Violence' to be filled obligatorily by reference services and Health Units ${ }^{(7)}$. Also described in this protocol are the care flows in cases of sexual violence and other types of violence.

Two more program editions of the Program were published in 2004 and 2008 with some modifications. The 2004 protocol had as main changes a greater detail of the flows of care, adding the organization to the attention to chronic sexual violence, a situation in which violence happens in a repetitive way, and for those who arrive at the service after 72 hours of the moment of the aggression, in these latter cases, the care would be provided by the Basic Health Units. In addition, there was a first modification of the daughter of notification with addition of some additional information on the nature of the violence suffered by the women ${ }^{(9)}$.

In the 2008 edition, there was a reformulation and adaptation of the notification form that was renamed "Compulsory Notification of Violence Against Women", which contains the typifications of violence according to Law 11340/06 (Maria da Penha Law). The fields of filling in the "Shared Care Decision" form were added, in which the woman authorizes or not to send the information contained in the Notification Form to the Women's Police Station and the Court Domestic Violence, as well as the sending to the service of your home. The flow of care also incorporates the various expressions of violence defined the referrals for each one ${ }^{(8)}$. 
In the 2008 protocol, for the first time, a section on the Intersectoral Network of Care for Women Victims of Violence was reserved in which the attributions and competences of different partners from different areas within the program are described. During this period and in subsequent years, a gradual expansion of the network with a greater articulation and supply of care services to women in situations of violence is observed.

The achievement of the Maria da Penha Law made possible a greater integration of actions among the organs, especially in the areas of Health and Social Action, and other institutions responsible for coping with violence against women, such as the Court of Domestic and Family Violence recently created in time, the Specialized Police Station for Women and civil society entities ${ }^{(8)}$.

Systematizations of the data of the Program, compiled from the database of mandatory notifications, are disseminated through annual reports with epidemiological analyzes (row 16 of Chart 2). These data are disseminated to the institutions that make up the Network and give visibility to the issue.

During the historical course of the Program and the Intersectoral Network, they received several awards (lines 11, 12 and 15 of Chart 2 ), and these experiences are considered innovative because it is one of the first national experiences of coping with violence against women, from Networking and notification, and for streamlining and humanizing sexual violence at the $9^{\text {th }}$ edition of the Mostra Nacional de Experiências Bem-Sucedidas em Epidemiologia, Prevenção e Controle de Doenças (National Exhibition of Successful Experiences in Epidemiology, Prevention and Control of Diseases). Their practices were considered successful in the implementation of the Maria da Penha Law in the "Good Practices in the Application, Dissemination and Implementation of Services", of the Office of Policies for Women of the Presidency of the Republic, in 2010, and finally, these experiences were recognized for helping to advance two millennium goals, gender equality and the reduction of child mortality in the Americas Award in 2012, in the category of reducing child mortality.

The scientific interest in the practices of the program culminated in the publication of several articles (lines 3, 4, 7, 8 and 14 of Chart 2) ${ }^{(10-13)}$, a dissertation and a thesis (lines 9 and 13 of Chart 2) ${ }^{(14-15)}$.

It was possible to identify in the dialogue with the sources that one of the significant actions listed as a coping strategy has been the training aimed at health professionals and the partners that compose the network, as well as the community that uses health services, universities, schools, centers municipalities of children's education, workers in the hospitality industry, military police, among others. This aspect was verified from 50 training/ qualification documents, which contained topics mainly addressed to present the program, for the identification, reception, orientation and referrals of VAW cases, the importance of the involvement of the multidisciplinary team in the addressing the problem, as well as guidelines for the use of the Compulsory Notification of Violence against Women.

\section{DISCUSSION}

The initiatives carried out in the city of Curitiba culminated in the elaboration of the Map of Risk of Violence (1997) ${ }^{(16)}$, one of the first governmental initiatives to obtain data on violence and investigations in the Clinic of the Medical Legal Institute and the Women's Police Station ${ }^{(17-18)}$. These initiatives put the municipality of Curitiba in line with the national and international movement to unveil violence, showing its scale and gravity at the local level, which in the municipality was little known.

The first Technical Standard on the Prevention and Treatment of Injuries resulting from sexual violence against women and adolescents ${ }^{(19)}$ was highlighted in the national movement regarding general violence and violence against women in 1999, and in 2001 of the Política Nacional de Redução da Morbimortalidade por Acidentes e Violências (National Policy for Reducing Morbidity and Mortality) due to Accidents and Violence, which is the legal basis for the health area up to the present day ${ }^{(20)}$.

At the international level, it became relevant in 1993 to the publication of the Pan American Health Organization that violence had become a public health problem in several countries. In view of this, it adopted Resolution XIX in which it called on the countries to develop policies to combat violence ${ }^{(21)}$. In 2002, the World Health Organization published the "World Report on Violence and Health", guiding document to address the health problem ${ }^{(22)}$.

Connected to those movements that recognized violence as a social phenomenon and a public health problem, this reinforced the city's discussions and concerns, imposing the need for organization and intersectorial confrontation, with both assistance and preventive perspectives.

The state resolutions mentioned above regulated the legal termination of pregnancy resulting from sexual violence and brought propositions that assistance services should be structured in the form of intersectoral networks, integrating and humanizing sexual violence services. These documents can be represented as advances in addressing violence against women, since they were important as a form of programmatic appropriation in the structuring of services in an intersectoral conception.

The flows of care structured in the Program through the protocols enabled innovations in the treatment of sexual violence, mainly through the partnership of the Municipal Health Office with reference hospitals and IML. This achievement, in addition to humanizing and diminishing the women's pilgrimage among services, has shown, with the inclusion of IML in the Program, greater horizontality, integration and resolution between the municipal and state levels. Furthermore, it can be affirmed that the IML service that was carried out in a legal perspective, takes place in this movement of articulation, of a more humanized conception.

Equally important is the discussion regarding the integration of services in dealing with violence against women. It can be seen that in this initial phase of the Intersectoral Network, the real integration of services occurred with the prioritization of the health and public safety sectors (women's police station, $\mathrm{IML}$ ) and justice, which shows that the network is created with a minimum of services intersectoral. In this way, it is understood that the demands of women in situations of violence go beyond the resolving power of these sectors, which imposes an articulated set of more comprehensive intersectoral actions ${ }^{(23)}$. 
Experiences of internal health programs that work articulated in an intersectoral network in the country are still rare and incipient ${ }^{(23)}$. However, we can mention some experiences known in this sense such as the Program of the Municipality of Campo Grande, Campinas and Campos dos Goytacazes.

The lluminar Program, in the city of Campinas, was structured in 2001, where a network for the organization of the flow of care was initially carried out, also focusing on sexual violence ${ }^{(24)}$ as the program analyzed in this article.

In the initial phase of the Curitiba Program, a large part of the content of the protocols, in the description of the competencies of the services and in the organization of the careflows, attention turns primarily to sexual violence, ie, there was a low focus on other forms of violence. Little intervention in violence other than sexual violence has been observed in several other studies that analyzed care services for women in situations of violence ${ }^{(23-25)}$.

This expansion of intersectorality and greater attention to other expressions of violence occurred mainly after the promulgation of the Maria da Penha Law, which envisaged networking with the creation of the Domestic and Family Violence Court against Women and the Reference Center of Care to Women Victim of Violence in Curitiba and Metropolitan Region (CRAMSV - Centro de Referência de Atendimento à Mulher em Situação de Violência de Curitiba e Região Metropolitana). The CRAMSV, created in 2006, with the role of articulating services, governmental and non-governmental institutions that integrate the women's care network, to guarantee access to comprehensive care, helped strengthen the Intersectoral Municipal Network, as it articulated itself in this movement dialogue with the entities to expand their performance.

The Court of Domestic and Family Violence articulated with the Intersectoral Network also represented a major milestone in the actions of violence against women in Curitiba city, ensured through articulation with the services that were part of the Network.

This expansion reoriented the actions of the Intersectoral Network for a more comprehensive care to women, adding actions of different entities, empowering intervention on the problem, considering violence against women a complex phenomenon that requires practices in different instances. This is in line with the literature that recognizes the complexity of this object, in which medical, health, social and cultural domains are linked, in which there is a need to consider the insufficiency of isolated areas to account for their apprehension and transformation ${ }^{(23)}$.

The lluminar Program is aimed at the person in a situation of violence, which differs from the Curitiba program that is directed at women in situations of violence. The organization of care was divided into two intersectoral networks, an indirect care network that included municipal schools, crèches, municipal councils, municipal guards, police stations, legal services, among others, and a network of direct care where urgent care takes place, such as specific health care with multiprofessional teams ${ }^{(24)}$.

In the city of Campos dos Goytacazes, in Rio de Janeiro State, the Center for Care, Research and Studies in the Domestic and Sexual Violence Area was created in 2010, focusing on people in situations of violence in three areas of health care, social assistance and assurance of rights. It was structured a service, articulated between the medical emergency and the system of guarantee of the rights, with the proposal of the subsequent multidisciplinary follow-up. It should be emphasized that the municipality also inserted the aggressor in the specialized care, including it in the screening of mental health services with referral to the Psychosocial Care Centers ${ }^{(26)}$. This last aspect, related to the attention to the aggressor is still an existing gap in the Curitiba Program, in addition, another distinction refers to the care directed to the person in situation of violence, including children, adolescents, men, women and elderly population.

A study carried out with health professionals in Rio Grande do Sul State showed the difficulties present for the construction of networks of articulated services to confront violence against women. He pointed out that health professionals recognize the importance of the network. However, they report that the lack of integration and disarticulation between these professionals and the network services lead to their ineffectiveness. They also point out that their lack of preparation for intersectoral attention contributes to the disarticulation between services ${ }^{(27)}$.

The experiences reported here demonstrate that at the local level, many programs and networks connect and is called 'attention to people', making it difficult to compare with the Program analyzed here. As the networks and programs of attention to violence are unique for each group (child and adolescent, woman and elderly), it is believed that this factor is a comparator.

However, it is well-known that advances, at the national level, from the elaborated policies, from the numerous local experiences built in the last two decades, are undeniable. However, it can be affirmed that there is still great vulnerability in the process of constructing perennial and homogeneous public policies at the country level as a whole.

Thus, the Programa de Atenção às Mulheres em Situação de Violência (Program of Care for Women Victims of Violence) and the Intersectoral Network in its historical trajectory advanced and consolidated their actions by implementing comprehensive and articulated practices, maintaining the action before successive municipal administrations.

\section{Study limitations}

One of the major limitations of the study refers to the difficulties of analyzing a local program of national importance and scope, with few experiences that allow national and/or international comparison.

\section{Contributions to the sectors of Nursing, Health or Public Policy}

Nursing, a profession that is mostly female, is the one that welcomes women in a situation of violence, and knowing and participating in the elaboration and execution of public policies is fundamental for confronting this violence. The health sector is one of the main places of reception of the grievances resulting from violence against women.

\section{FINAL CONSIDERATIONS}

Domestic and sexual violence against women is an important public health problem with high individual and social costs. Its confrontation requires an organizational and intersectorial restructuring, aiming to respond to its effects (physical, emotional, legal, social, security, among others). 
The Historical Path of the Program researched here guides its action in this perspective and has been an important locus of implementation of public policies at local and national level. In the health sector, investments in organizing sectoral and intersectoral flows are highlighted through the publication of the protocols, establishing the line of care and concentrated attention between IML, Women's Police Station and Hospital Referral Services for sexual violence in a single local, which allowed the reduction of the critical route, institutional violence and the humanization of care, as well as the reduction of unwanted pregnancies due to rape and STDs and HIV.
Other aspects to be highlighted are the progress made by the Rede Intersetorial de Atenção às Mulheres em Situação de Violência (Intersectoral Network of Care to Women Victims of Violence), especially after the promulgation of the Maria da Penha Law and the expansion of services with the creation of the Specialized Judiciary, Public Defender's Office and Reference Center, implementation social services (CRAS and CREAS). Thus, it is visualized as multiple contextual factors interacted with the Network, to construct a more adequate proposal to address the complexity of violence, resulting in a particular experience with a more structured network and with a more strengthened and comprehensive intersectoriality.

\section{REFERENCES}

1. Organização Mundial da Saúde-OMS. Estimaciones mundiales y regionales de la violencia contra la mujer: prevalencia y efectos de la violencia conyugal y de la violencia sexual no conyugal en la salud; Genebra: OMS; 2013.

2. Lacey K, Mouzon D. The mental and physical health of severely and non-severely abused U.S. Black Caribbean women. West Indian Med J Suppl[Internet]. 2015[cited 2017 Jun 15]. Available from: http://search.bvsalud.org/cvsp/resource/en/med-17998

3. Brasil. Ministério da Saúde. Secretaria de Vigilância em Saúde. Violência contra mulher: o desafio de articulação da vigilância com a rede de proteção e atenção Saúde Brasil 2015/2016: uma análise da situação de saúde e da epidemia pelo vírus Zika e por outras doenças transmitidas pelo Aedes aegypti. Brasília: Ministério da Saúde; 2016. 386 p.

4. Waiselfisz JJ. Mapa da Violência 2015: Homicídio de mulheres no Brasil. Rio de Janeiro: Flasco; 2015. 83 p.

5. Barros, JA. O campo da história: especialidades e abordagens. 6. ed. Petrópolis, RJ: Vozes; 2008.

6. Instituto Paranaense de Desenvolvimento Econômico e Social-IPARDES. Perfil avançado do município de Curitiba[Internet]. 2015[cited 2017 Jun 10]. Available from: http://www.ipardes.gov.br/perfil_municipal/MontaPerfil.php?codlocal =5\&btOk=ok

7. Secretaria Municipal de Saúde. Protocolo de Atenção a Mulher Vítima de Violência. Curitiba; 2002.

8. Secretaria Municipal de Saúde. Protocolo de Atenção a Mulher em Situação de Violência Curitiba: Saúde Levada a Sério. Curitiba; 2008.

9. Secretaria Municipal de Saúde. Protocolo de Atenção a Mulher Vítima de Violência. Curitiba; 2004.

10. Shimazaki ME, Lopes MGD, Oliveira VL. A. Saúde sim, violência não: Programa Mulher de Verdade. Jornal Fêmea[Internet]. 2002[cited 2017 Jun 10];(117). Available from: http://www.cfemea.org.br/index.php/colecao-femea-e-publicacoes/ colecao-femea/101-numero-117-outubro-de-2002

11. Oliveira VLA. Ações de vigilância, prevenção e atenção à violência em Curitiba. In: Violência: uma epidemia silenciosa, Seminários Regionais. Brasília: CONASS; 2008. p.19-20.

12. Santos TAA. Centro de referência e atendimento psicossocial e jurídico à mulher em situação de violência de Curitiba e região metropolitana. In: Violência: uma epidemia silenciosa, Seminários Regionais. Brasília: CONASS; 2008. p.20-22.

13. Duarte AHC, Coning SGS. Vítimas de violência sexual e desafios na prática multiprofissional: breves apontamentos. Anais do II Simpósio Gênero e Políticas Públicas. Universidade Estadual de Londrina. 2011.

14. Corrêa MEC, Labronici LM. A enfermeira desvelando o significado do atendimento às vítimas de violência sexual expresso pelos profissionais de Saúde[Dissertação]. Curitiba: Universidade Federal do Paraná; 2008.

15. Okabe I. Violência contra a mulher: uma proposta de indicadores de gênero na família[Tese]. São Paulo: Escola de Enfermagem, Universidade de São Paulo; 2010.

16. Centro de Estudos de Cultura Contemporânea-CEDEC. Mapa de Risco da Violência da Cidade de Curitiba. São Paulo: CEDEC; 1997.

17. Prefeitura Municipal de Curitiba. Instituto de Pesquisa e Planejamento Urbano, Secretaria Municipal de Saúde. Violência urbana: ocorrências, agressores e vítimas, Levantamento realizado no IML - Clínica Médico Legal. Curitiba; 1999.

18. Prefeitura Municipal de Curitiba. Instituto de Pesquisa e Planejamento Urbano. Secretaria Municipal de Saúde; Secretaria de Estado de Segurança Pública. Violência contra a mulher: vítimas e agressores levantamento realizado na Delegacia da Mulher. Curitiba; 2001.

19. Brasil. Ministério da Saúde. Norma Técnica de Prevenção e Tratamento dos agravos resultantes da violência sexual contra mulheres e adolescentes. Brasília: MS; 1999.

20. Brasil. Ministério da Saúde. Portaria MS/GM n. 737, 16 de maio de 2001. Política nacional de redução da morbimortalidade por acidentes e violências. Diário Oficial da República Federativa do Brasil. 2001 maio 18. Seção 1e. 62 p.

21. Organización Panamericana de la Salud-OPAS. Resolución XIX: Violencia y Salud. Washington, DC: OPAS; 1993. 
22. Organização Mundial de Saúde-OMS. Organización Panamericana de la Salud-OPAS Relatório mundial sobre violência e saúde. Brasília: OMS/OPAS; 2002.

23. D'Oliveira AFPL, Schraiber LB, Hanada H, Durand J. Atenção integral à saúde de mulheres em situação de violência de gênero: uma alternativa para a atenção primária em saúde. Ciênc Saúde Colet[internet]. 2009[cited 2017 Jun 05];14(4):1037-50. Available from: http://www.scielo.br/pdf/csc/v14n4/a06v14n4.pdf

24. Pedrosa CM, Diniz CSG, Moura VGAL. O Programa lluminar Campinas: a construção de uma política intersetorial e interinstitucional para o enfrentamento da violência como um problema social. Ciênc Saúde Colet[internet]. 2016[cited 2017 May 28];21(6):187987. Available from: http://www.scielo.br/pdf/csc/v21n6/1413-8123-csc-21-06-1879.pdf

25. D'Oliveira AFPL, Schraiber LB. Identificando possibilidades e limites do trabalho em rede para a redução da violência contra a mulher: estudo entre três capitais brasileiras. In: SENASP. Relatório de pesquisa. Brasília: Ministério da Justiça; 2006.

26. Kury $\mathrm{CMH}$, Kury MMH, Pereira CCR, Oliveira FA, Oliveira, FC, Silva RMH, et al. Implantação de um centro na área das violências doméstica e sexual em Campos do Goytacazes, Rio de Janeiro, 2009-2012. Epidemiol Serv Saúde[internet]. 2015 [cited 2017 Jun 02];24(4):771-6. Available from: http://www.scielo.br/pdf/ress/v24n4/2237-9622-ress-24-04-00771.pdf

27. Arboit J, Padoin SMM, Vieira LB, Paula CC, Costa MC, Cortes LF. Health care for women in situations of violence: discoordination of network professionals. Rev Esc Enferm USP[internet]. 2017[cited 2017 Jun 28];51:e03207. Available from: http://www.scielo. $\mathrm{br} / \mathrm{pdf} /$ reeusp/v51/pt_1980-220X-reeusp-51-e03207.pdf 